Prace Literackie LVI

Wrocław 2016

DOI: $10.19195 / 0079-4767.56 .7$

DARIUSZ PIECHOTA

Uniwersytet Marii Curie-Skłodowskiej w Lublinie

\title{
Hipsterzy w lustrze dekadentów
}

Bohater Królowej Śniegu (2014) podczas przyjęcia sylwestrowego stwierdza: „Lepiej tak naprawdę odejść w blasku sławy. Dlatego kochamy Marilyn i Jamesa Deana. Kochamy tych, którzy wchodzą prosto w płomienie"1. Nie sposób nie zgodzić się ze słowami Pinga. Współcześni mieszkańcy ponowoczesności uwielbiają śledzić losy outsiderów, ekscentryków, osób o zaburzeniach typu borderline, którzy odrzucają powszechnie obowiązujące wzorce normatywne oraz styl życia typowy dla filistrów. W swoim zachowaniu eksponują pogardliwy stosunek wobec normalności i przeciętności, utożsamianych z rutynowym życiem mieszczan. Nijakość oraz materializm społeczeństwa to główne źródła oporu oraz krytyki. Podporządkowanie egzystencji konwenansom i popularnym rolom społecznym narzucającym jednostce określony sposób istnienia w przestrzeni społecznej sprawia, iż życie dla „wyrzutków” staje się źródłem permanentnego cierpienia.

Warto przypomnieć, iż bunt wobec powszechnie obowiązujących zasad w społeczeństwie szczególnie popularny okazał się w XIX wieku. Nie tylko romantycy, lecz także dekadenci przeciwstawiali się wzorcom normatywnym zniewalającym jednostkę. Kontestatorzy chętnie współtworzyli subkultury, bohemy artystyczne, w których obrębie próbowali przebudować świat, kreując nową, utopijną rzeczywistość odrzucającą wszelkie wewnętrzne podziały na rzecz jedności. Warto podkreślić za Tomaszem Weissem, iż „cyganerie powstają w ścisłym związku z przełomami społecznymi, ekonomicznymi, są niejako produktem ta-

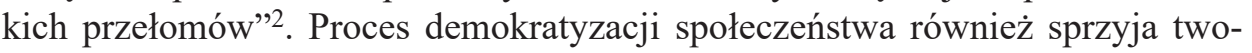
rzeniu się bohem artystycznych buntujących się przeciwko filisterskiemu stylowi życia. U schyłku XIX wieku narodziny cyganerii krakowskiej ściśle wiązały się z powszechnym w całej Europie poczuciem nieuchronnie zbliżającego się kresu. Świat dla dekadentów stał się „tworem chaotycznym, pozbawionym rozumnego celu, niejednolitym, nie opartym na istnieniu prawa, które tłumaczyłoby sens

\footnotetext{
${ }^{1}$ M. Cunningham, Królowa śniegu, przeł. J. Kozłowski, Poznań 2014, s. 123.

2 T. Weiss, Cyganeria Młodej Polski, Kraków 1970, s. 18.
} 
ludzkiego życia"3. Podobnie na początku XXI wieku kryzys wartości i duchowości, jak też konsumpcjonistyczny styl życia okazały się źródłem krytyki ponowoczesnej kultury.

Niejednokrotnie outsiderzy ,zabijali” swój wewnętrzny weltschmerz alkoholem, kawą oraz narkotykami. Dążyli do intensyfikacji uczuć poprzez spożywanie różnorakich używek. Nieobce było im eksperymentowanie w sferze seksualnej ${ }^{4}$, co wynikało z faktu, iż egzystencja miała dla nich wartość ulotną i efemeryczną. Kontestatorzy żyli chwilą, co stało się priorytetową zasadą stymulującą ich do działania.

Poszukiwanie własnej tożsamości okazuje się zadaniem niezwykle trudnym oraz skomplikowanym. $Z$ jednej strony outsiderzy żyją w świecie, który ulega nieustannemu procesowi modernizacji, $\mathrm{z}$ drugiej zaś ciągle tkwią $\mathrm{w}$ zaściankowości symbolicznie eliminującej wszelkie działania twórcze odbiegające od obowiązującej kultury mieszczańskiej. Bunt stał się twórczy dla wielu pokoleń nie tylko romantyków, dekadentów, przedstawicieli ruchu Flower Power, hipisów, wyznawców New Age, lecz także hipsterów. Aleksandra Litorowicz w Subkulturze hipsterów zwróciła uwagę, iż grupa ta związana jest z beatnikami, ,jazzowym zgiełkiem" lat czterdziestych XX wieku ${ }^{5}$, a jego przedstawiciele stali się dziećmi historii pierwszej połowy XX wieku ${ }^{6}$. Ale czy rzeczywiście ideały hipsterów związane są wyłącznie z ideałami beatników? Czy przypadkiem ich światopogląd nie sięga korzeniami schyłku XIX wieku, kiedy rozwija się kultura fin de siècle? W niniejszym szkicu postaram się przyjrzeć relacji dekandent-hipster, uwzględniając między innymi ich światopoglądy oraz style ubierania się.

\section{Fin de siècle nad Wisłą. Światopogląd hipsterów}

Przypomnijmy, iż słowo hipster pochodzi z języka afrykańskiego ludu Wolof. Hip oznacza w nim oświeconego, który ma oczy otwarte ${ }^{7}$. Termin ten pojawił się w raporcie Camela z 1994 roku; autor określił hipsterów jako „mieszkańców kosmopolitycznych metropolii, których życie toczy się wokół klubów, muzyki i mody" 8 . Wzrost zainteresowania tą subkulturą w Polsce nastąpił pod koniec pierwszej dekady XXI wieku9 ${ }^{9}$. Zgodnie z popularnie wykreowanym stereotypem typowy hipster pije mocne espresso, pali marihuanę, zna pisma egzystencjalistów,

${ }^{3}$ Ibidem, s. 45.

4 Por. T. Walas, Ku otchtani. Dekadentyzm w literaturze polskiej 1890-1905, Kraków 1986, s. 78 .

5 A. Litorowicz, Subkultura hipsterów. Od nowoczesnej etyki do ponowoczesnej estetyki, Gdańsk 2012, s. 14.

6 Ibidem, s. 27.

7 R. Księżyk, Hipster, „Machina” 2008, nr 1, s. 90.

8 Ibidem, s. 92.

9 A. Litorowicz, op. cit., s. 6. 
niekiedy nadużywa alkoholu ${ }^{10}$. Nawiasem mówiąc, wszelkie używki były niezwykle inspirujące dla dekadentów ${ }^{11}$, dla których czarna kawa stała się „koniecznym atrybutem koleżeńskich zebrań" ${ }^{2}$. Ponowoczesny hipster stał się „pożeraczem” trendów, fanem muzyki alternatywnej, lewicującym liberałem opowiadającym się za „etyką konsumpcji”, to „outsider porzucający senne przedmieścia”"13. Podobnie jak dziewiętnastowieczni schyłkowcy odrzuca przeszłość oraz przyszłość, koncentrując się na teraźniejszości. Zgodnie z filozofią ponowoczesnej subkultury należy żyć intensywnie, niczym hedoniści korzystać z tego, co najlepsze, niejednokrotnie przekraczając granice tabu. Dlatego też nieobce są im „rozkosze ciała, narkotykowe eskapady, szaleńcza jazda samochodem"14.

Hipster, tak jak dekadent-artysta, odrzuca rodzinę, pieniądze, bezpieczeństwo. Poszukuje nie tylko prawdy, ale też sensu własnej egzystencji. Kluczowym zadaniem dla jednostki w świecie ponowoczesnym staje się poznanie samego siebie. Dlatego też „skleja on” swoją rzeczywistość, „wykorzystując kod czarnego człowieka, absorbuje jego egzystencjalne synapsy"15. To bohater w nieustannej drodze, co wynika z kontestacji współczesnej kultury konsumpcyjnej. Pamiętajmy, iż wszelkie cyganerie stanowiły zaprzeczenie poczucia stabilizacji oraz bezpieczeństwa ${ }^{16}$. Podobnie jak dekadenci są świadomi nieuchronnego kresu. Społeczeństwo staje się dla nich źródłem opresji. Co więcej, przedstawiciele ponowoczesnej subkultury odczuwają, iż końcem ludzkiej egzystencji jest śmierć, więzienie bądź zakład psychiatryczny ${ }^{17}$.

Hipster, podobnie jak dekadent, uwikłany jest w konflikt ze społeczeństwem, który odzwierciedla opozycja squar-hipster. Square (z ang. „kwadratowy”) przypomina dziewiętnastowiecznego filistra, gdyż uosabia mieszczańską etykietę, moralność, purytanizm oraz konformizm. Świat squarów „to świat uporządkowany, którego fundamentami są wszelkiego rodzaju umowy społeczne, w pojęciu hipstera oznaczające pracę, rodzinę, odpowiedzialność obywatelską i dążenie do dobrobytu"18. Członkowie tej subkultury buntują się przeciwko ustabilizowanemu, rutynowemu stylowi życia klasy średniej, z pogardą odnoszą się do karierowiczów, mieszczuchów niejednokrotnie kierujących się podwójnymi standardami moralności. Wyrażają także ,pogardę dla pracy w korporacjach, korzystania z wyrobów dużych firm, a także ubierania się w sieciowych sklepach" ${ }^{19}$. Świat squarów, podobnie jak filistrów, cechuje zaściankowość, pycha, głupota oraz konserwatyzm.

\footnotetext{
10 Ibidem, s. 13.

11 Por. T. Walas, op. cit., s. 59.

12 T. Weiss, op. cit., s. 92.

13 R. Księżyk, op. cit., s. 92.

14 A. Litorowicz, op. cit., s. 22.

15 Ibidem, s. 29.

16 T. Weiss, op. cit., s. 187.

17 A. Litorowicz, op. cit., s. 43.

18 Ibidem, s. 19.

19 Ibidem, s. 101.
} 
Dla hipsterów życie na krawędzi okazuje się kontrargumentem wobec ustabilizowanego życia mieszczuchów cierpiących na „delirium” konsumpcji. Perwersyjny pociąg do śmierci ${ }^{20}$ był niezwykle bliski dekadentom. Hipsterzy świadomie pogrążają się $\mathrm{w}$ autodestrukcji, co może być również efektem nasilającej się depresji, fobii, lęków oraz innych zaburzeń natury psychicznej. Żyją ,„z silnym psychologicznym pragnieniem śmierci, chłodu (cool), odosobnienia"21. Zgodnie z ich filozofią należy żyć intensywnie, gdyż w przyszłości czeka nas kolejna wojna światowa bądź wybuch bomby atomowej. Niewątpliwie bliska jest im poetyka postapokaliptyczna.

Hipsterzy, tak jak dekadenci, przynależą do miasta. Metropolia staje się dla nich przestrzenią działania, miejscem nieustannej konsumpcji oraz tworzenia własnego image'u. Zgodnie z podjętą próbą wykreowania życia jako formy sztuki, ponowoczesna rzeczywistość przypomina wielki teatr, w którym przedstawiciele subkultury poszukują dla siebie odpowiedniej roli społecznej.

\section{Moda i styl życia}

Pierwsi hipsterzy włóczyli się po barach dla outsiderów na Times Square, gdzie spożywając różnego rodzaju używki, pogrążali się w autodestrukcji. Ubrani w dżinsy, czarne swetry (będące znakiem kontestacji) podobnie jak dekadenci odwiedzali modne lokale, poszukując w nich inspiracji do działania (niekiedy przyjmowały one formę prowokacji oraz buntu w sferze obyczajowej). Warto podkreślić, iż w obu subkulturach ważną rolę odgrywa strój, będący ,,prowokacyjnym protestem przeciwko mieszczańskiemu społeczeństwu"22. Przypomnijmy, iż dekadenci nie strzygli głów, szokując bujnym owłosieniem, nosili przeważnie długie włosy oraz brody (niezbędny atrybut hipstera), która stanowiła synonim rewolucyjnych poglądów jego właściciela ${ }^{23}$. Z kolei typowe elementy garderoby hipstera to: dżinsy rurki bądź leginsy; oryginalne, ironiczne T-shirty; buty typu sneakers, szaliki zakładane latem, flanelowe koszule, okulary marki Ray-Ban, trampki Converse.

Aleksandra Litorowicz wśród hipsterów wyróżnia dwa typy ${ }^{24}$. Pierwszym z nich jest hipster-innowator, który koncentruje się na tworzeniu nowych rzeczy w procesie nieustannego recyclingu. Pamiętajmy, iż hipster pragnie być oryginalny, starając się wyprzedzać trendy w modzie. Niejednokrotnie przerabiając stare ubrania, tworzy konstrukcje patchworkowe, co nawiasem mówiąc, kojarzy się

20 T. Weiss, op. cit., s. 72.

21 L. Elektorowicz, Zwierciadło w okruchach. Szkice o powieści amerykańskiej i angielskiej, Warszawa 1966, s. 180.

22 T. Weiss, op. cit., s. 141.

23 Ibidem, s. 37.

24 A. Litorowicz, op. cit., s. 63. 
z modą steampunkową ${ }^{25}$. Bohater pragnie stworzyć dzieło oryginalne, ponadczasowe, co w świecie ponowoczesnym jest zadaniem niezwykle trudnym. Dlatego też „hipsteryzm zakłada miksowanie trendów, ogromny eklektyzm, indywidualistyczne podejście do ubioru"26. Przedstawiciele tej subkultury żyją w cieniu mody vintage. Niejednokrotnie szukają oryginalnych, niepowtarzalnych ubrań w sklepach typu second-hand, które poddają następnie obróbce. To nieustanne „miksowanie” grunge'u z glamourem ${ }^{27}$. Drugi typ hipstera to baczny naśladowca najnowszych trendów oraz zjawisk społecznych będących na topie, które bezrefleksyjnie wciela w swoje życie. Jego egzystencja wydaje się sztuczna, pozbawiona autorefleksji. Typ ten rezygnuje z samodzielnego tworzenia, powielając produkty wytworzone przez hipstera-innowatora.

Przedstawiciele tej subkultury postrzegają tworzenie jako formę ekspresji wynikającej „Z autentycznego zaangażowania, pasji oraz wewnętrznej potrzeby”28. W przeciwieństwie do dekadentów hipsterzy gloryfikują twórczą kreatywność, która staje się dla nich sposobem na życie.

\section{Język hipstera}

Oprócz stroju ważną rolę w subkulturach odgrywa język, a dokładnie jej żargon. Dekadenci ,stworzyli odrębne słownictwo, posługując się umówionymi znakami słownymi, zrozumiałymi jedynie dla wtajemniczonych, co było jeszcze jednym sposobem podkreślenia swojej odrębności"29. Ich język pełny jest wyrażeń hiperbolicznych oraz neologizmów. Podobnie hipsterzy posługują się odrębnym językiem zwanym hipjęzykiem, zaczerpniętym ze słownictwa muzycznego ${ }^{30}$. Przedstawiciele tej subkultury wielokrotnie rozpoczynają wypowiedź od słowa like, czyli „tak jakby, jak gdyby”31, co sygnalizuje nie tylko pewną iluzoryczność, lecz także sugeruje przyjęcie postawy eskapistycznej przejawiającej się w ucieczce od szarej, monotonnej rzeczywistości klasy średniej. Hipsterzy są małomówni, co wynika z faktu, iż milczenie w ich subkulturze jest znaczącą formą komunikacji. Pełni ono również funkcję symboliczną, sugerując, iż rozmówcy rozmyślają o czymś wzniosłym, niezwiązanym z kulturą masową mieszczan. Ich wyważone słowa mogą świadczyć o wykreowanym wizerunku (pseudo)intelektualisty, jak też przemyślanej strategii życiowej. Hipjęzykiem posługuje się Jo. Bohaterka Gier losowych (2014) w rozmowie z koleżanką używa zwrotów typu: „co u cie-

25 Więcej na ten temat piszę w szkicu: Moda retro $w$ zwierciadle steampunku, „Fragile” 2014 nr 1 (23).

26 A. Litorowicz, op. cit., s. 68.

27 Ibidem, s. 69.

28 Ibidem, s. 85.

29 T. Weiss, op. cit., s. 37

30 A. Litorowicz, op. cit., s. 32.

31 Ibidem, s. 23. 
bie?”, „świetnie wyglądasz”, ,jak sobie radzisz?”, które tylko pozornie świadczą o jej zaangażowaniu emocjonalnym. Tak naprawdę Jo nie interesuje się życiem przyjaciółki, co potwierdza fakt, iż podczas spotkań głównie milczy. Wybiera milczenie jako strategię życiową, ponieważ jest ono modne.

\section{Hipster w krzywym zwierciadle}

Postać hipstera, podobnie jak dekadenta, szybko została spopularyzowana przez mainstream, stając się atrakcyjnym tematem dla czytelników literatury popularnej. Autorzy, charakteryzując outsiderów, chętnie posługują się cliché, które „usprawniają i przyśpieszają czytanie, jednocześnie odpowiednio je orientując i modelując"32, co wyjaśniałoby częstotliwość ich występowania w literaturze popularnej. Dlatego też w wizerunku dekadenta podkreślano wyrazistość oraz schematyczność postaci, jednocześnie wyśmiewając jego światopogląd czy styl życia (np. w Pamiętniku Munia Michała Bałuckiego, Mgłach Mariana Galewicza czy w Hrabim Auguście Augusta Mańkowskiego). Subkultura hipsterów, podobnie jak schyłkowców XIX wieku, ,szybko stała się źródłem powszechnej krytyki; zarzucano im »pozerstwo«, powierzchowne czerpanie z etosu kontrkulturowego i niemożność wytwarzania jakichkolwiek wartości"33.

W najnowszej prozie ukazującej zjawisko hipsteryzmu w krzywym zwierciadle hipsterzy stają się drugoplanowym bohaterem zbiorowym, przesiadującym większość czasu w popularnych kawiarniach, pijącym espresso, dyskutującym na temat najnowszych trendów mody, jednocześnie będąc nieustannie aktywnym na portalach społecznościowych. Wizerunek ten pojawia się między innymi w Kochanie, zabiłam nasze koty (2012) Doroty Masłowskiej. Bohaterka powieści Joanne pracuje w zakładzie fryzjerskim przy Bohemian Street, na której znajdują się liczne modne kawiarnie często odwiedzane przez młodych nastolatków. Już sama nazwa ulicy (z ang. „cyganeria”) sugeruje wyjątkowość tego miejsca, w którym chętnie gromadzą się przedstawiciele różnych subkultur. Najpopularniejszym miejscem staje się „lokal Bad Berry, gdzie jak dzień długi wysiadują rozmaite dziwadła, manifestując światu swoją wyjątkowość, której trzpień, jak się potem okazuje, zlokalizowany jest w oprawkach od okularów"34. Masłowska wyśmiewa hipsterowską obsesję na punkcie określonych marek, które mają nadać ich egzystencji dodatkowej wartości (preferowane oprawki okularów powinny być firmy Ray-Ban). Autorka Pawia Królowej szyderczo wyśmiewa nietypowy styl ubierania się hipsterów. Bohaterka powieści zauważa na ulicy wymięte hipsterki „w czapkach

32 I. Poniatowska, Modernizm bez granic. Wielkie tematy nowoczesności w polskich powieściach popularnych drugiej połowy XIX wieku, Warszawa 2014, s. 49.

33 A. Litorowicz, op. cit., s. 7.

34 D. Masłowska, Kochanie, zabiłam nasze koty, Warszawa 2012, s. 16. Wszystkie cytaty $\mathrm{z}$ powieści pochodzą z tego wydania. Po cytacie podaję w nawiasach numery strony. 
do wspinaczki górskiej mimo upału, z torebkami przypominającymi stare moszny" (s. 16). Hipsterzy w Kochanie, zabiłam nasze koty udają się na zakupy do sklepów z używaną odzieżą na St. Patrick's w poszukiwaniu oldschoolowych ubrań oraz gadżetów. Jednym z nich jest gumowa okładka Kazań Piotra Skargi, o której Farah stwierdza:

Zwariowany gadżet — można ją nałożyć na dowolną książkę i spędzić popołudnie w Bad Berry, popijając sojowe latte za osiem dolców i zza raybanów łowić spojrzenia tych wszystkich sympatetycznych więźniów własnej przewidywalności... (s. 104-105)

Oprócz wyglądu zewnętrznego obiektem drwin staje się ich styl życia, w którym kluczową rolę odgrywa aspekt twórczy. Przedstawiciele tej subkultury pragną wykonywać zawód związany ze sztuką. Co więcej, niczym dekadenci marzą, aby ich życie przypominało dzieło sztuki. Pragnienie takie odczuwa Go projektująca ulotki, które uważa za arcydzieła, sama zaś uznaje siebie za artystkę. Podobne marzenia ma również Jed, właściciel salonu fryzjerskiego o symbolicznej nazwie „Hairdonism”. Bohater „w niezwykłych marynarkach i włoskich butach, swojemu zakładowi usiłuje nadać artystowski sznyt, zapychając każdą szparę książkami wielkiej przypadkowości, kupowanymi hurtem [...]" (s. 46). Z kolei Dean Jordan, brat protagonistki, handluje starymi grami komputerowymi, co wiąże się z hipsterską obsesją związaną ze stylem vintage. Hipsterzy często uczestniczą w wernisażach, na których zgodnie z powszechną modą warto bywać. Co więcej, można na nich spotkać kultowych artystów. Farah:

wmieszała się w grupkę zwariowanych odszczepieńców. Ze swoimi wełnianymi, memłanymi wciąż w palcach brodami wyglądali, jakby całkiem na świeżo obrabowali stado kóz, a teraz wspólnie radowali się sprawiedliwie podzielonymi łupami. Któryś z nich podał Farah skręta, a potem, gdy powiedziała mu szczerze, że nie nazywa się Tracy, zabrał go, a F. znowu stała sama, obserwując staruszki z aparatami słuchowymi. Choć trudno im było ukryć, że ze wszystkich eksponatów najbardziej zafrapowały je darmowe snacki, to zaraz po konsumpcji, by nie zostawiać twórcy z niczym, uczciwie obeszły wystawę, wygłaszając parę donośnych, nieraniących nikogo opinii („to zastanawiające”, „i takie nietypowe”). Uderzająca w mieszczańskie przywiązanie do konwencji i tych małych obłudnych rytuałów ekspozycja przedstawiała między innymi pocięte kawałki pościeli (s. 80-81).

Okazuje się, iż nowoczesna sztuka jest niezrozumiała zarówno dla hipsterów, jak i pozostałych grup społecznych. W trakcie oglądania wystawy posługują się utartymi frazesami, które w ich przekonaniu potwierdzają znajomość najnowszych trendów w sztuce. Tak naprawdę wernisaże okazują się dla nich dobrym miejscem do wypalenia skręta oraz wypicia darmowego alkoholu.

Przedmiotem drwiny w powieści Masłowskiej staje się również obsesyjne myślenie o samotności oraz śmierci. Joanne czyta artykuły o immanentnej samotności, celowo osiągając stan depresyjny. Kreowanie sztucznych stanów emocjonalnych to jedna z masek, jaką przyjmują ponowocześni hipsterzy. Autorka Kochanie, zabiłam nasze koty wyśmiewa sztuczne dylematy egzystencjalne przypisywane przedstawicielom tej subkultury, zachęcając zgodnie z ulotką reklamową do zabiegu pomniejszenia mózgu: 
(„Pomniejszanie mózgu! Za dużo myślisz? Wspominasz? Rozważasz? Zastanawiasz się, dlaczego spotkało cię tyle cierpienia? Pomniejszenie mózgu wybawi cię od tych kłopotów").

(„Pomniejsz mózg, bądź roześmiany i naprawdę ciesz się życiem”) (s. 33).

Hipsterzy epizodycznie pojawiają się również w powieści Pauliny Klepacz Daj mi więcej (2015). Protagonistka utworu często spotyka przedstawicieli tej subkultury w klubach typu Glow, a także na targach staroci, gdzie poszukują rozmaitych bibelotów oraz mebli w stylu vintage. Podobnie jak w powieści Masłowskiej mekką hipsterów stają się wernisaże. W rozmowie z Polą, Maks stwierdza:

Zabieram cię na wernisaż prac młodego, zdolnego malarza, och, Jan Kęss, czy coś takiego. A może January... Oni mają teraz takie hipsterskie imiona i nazwiska ${ }^{35}$.

Na uwagę czytelnika zasługuje określenie „hipsterskie”, które już nie odnosi się do światopoglądu czy stylu ubierania, lecz do samego człowieka. Określone imiona w symboliczny sposób zostają przywłaszczone przez subkulturę, co wydaje się dość absurdalne. Podążając tym tropem, możemy stwierdzić, iż niektórzy rodzą się (a nie stają się) już hipsterami.

Przedstawiciele tej grupy są głównym bohaterem powieści Gry losowe (2014) Joanny Dziwak ${ }^{36}$. Na początku pragnę podkreślić, iż utwór ten ma konstrukcję patchworkową; autorka „zszywa” kilka opowieści w jedną całość, dekonstruując choćby motyw American Dream o szybkiej karierze w branży muzycznej czy pisarskiej. W powieści Dziwak hipsterzy stanowią efemeryczną grupę. Podobnie jak Masłowska przedstawia subkulturę w krzywym zwierciadle, wyśmiewając styl życia oraz światopogląd jej przedstawicieli.

Autorka krytykuje hipsterską obsesję podążania za nowymi trendami. Już na początku historii dowiadujemy się, iż kolejną tendencją w ponowoczesnej rzeczywistości ma być moda na wyższe wartości:

Moda na bycie uduchowionym wymaga od swoich wyznawców sporych nakładów finansowych, a biomleko od oświeconej kozy z ekologicznego gospodarstwa w Nepalu kosztuje dziesięć razy więcej niż mleko swoistej, amerykańskiej krowy, która nigdy nie słyszała nawet o samsarze, a nirwana kojarzy jej się najwyżej z zespołem słuchanym przez obdarte dzieci sąsiadów ładnych parę lat temu (s. 75).

Moda na duchowość okazuje się chwilowym wykreowanym trendem wymagającym od przedstawicieli subkultury konkretnych nakładów finansowych. Popularna staje się również depresja. W aptekach sprzedaje się depresanty bez recepty, psychoterapeuci organizują depresyjne warsztaty, w których uczestniczą między innymi członkowie grupy Zespół Tam Gdzie Kończy się Ironia, a Zaczyna Depresja. Dziwak szydzi ze sztucznie kreowanego stanu melancholii. Celem organizowanych warsztatów staje się wywołanie depresji wśród uczestników, co w rezultacie zapewni im sławę: „Fejm prowadzi do depresji, depresja wzboga-

35 P. Klepacz, Daj mi więcej, Warszawa 2015, s. 127.

36 J. Dziwak, Gry losowe, Kraków 2014. 
ca i uszlachetnia fejm" (s. 128). Nawiasem mówiąc, w ponowoczesnym świecie organizowane są także zjazdy „Najbardziej Depresyjnych Autorów Świata” (s. 147). Hipsterzy, podążając za trendami, czytają między innymi Schopenhauera (Świat jako wola i przedstawienie), zamiast pić wódkę palą marihuanę, twierdząc, iż ,to skręt jest znakiem wyjściowym cyganerii dwudziestego wieku” (s. 106). Paradoksalnie „słuchają zespołów, które jeszcze nie istnieją” (s. 115), a przebojem będącym leitmotivem powieści staje się przeróbka hitu Anny Jantar Tyle mroku $w$ catym mieście.

Podobnie jak u Masłowskiej przedstawiciele ponowoczesnej subkultury większość wolnego czasu spędzają w modnych lokalach, wpatrzeni w swoje smartfony, znudzeni dostępnymi aplikacjami na iPhone’a żyją na granicy świata realnego oraz wirtualnego. Dziwak krytykuje pozorny bunt młodego pokolenia:

Zapytani o „szczytne cele” rzucali hasła: chuje politycy, chuje korporacje, rewolucja i nierówność społeczna, po czym z oburzeniem nieschodzącym z twarzy przez dwadzieścia cztery godziny na dobę zamawiali napoje i przystawki za pieniądze bogatych rodziców [...] Oburzeni skupiali się na konsumpcji (s. 76).

Autorka dostrzega hipokryzję w ich postępowaniu; z jednej strony buntują się przeciwko niesprawiedliwości społecznej, z drugiej zaś bez jakiejkolwiek refleksji korzystają z dóbr materialnych tego świata, dzięki nielimitowanemu dostępowi do kart kredytowych rodziców. Dziwak wyśmiewa rzekomą rewolucję hipsterów, która ogranicza się wyłącznie do górnolotnych sloganów:

Światu potrzebna jest rewolucja - twierdzi ona - Jej skrzydło wyora naszą ziemię, lecz wcześniej epoka kultury nastanie. Artyści wyjdą na ulice, manifestować będą, krzycząc: mamy propozycję, by żyć w alternatywnej rzeczywistości (s. 105-106).

Ich filozofia ogranicza się, cytując wiersz jednego z bohaterów, do: „legs, late, latte, lateks, seks" (s. 105). Przedstawiciele tej subkultury, podobnie jak dziewiętnastowieczni schyłkowcy, pogrążają się w konsumpcji oraz (nie)świadomej autodestrukcji. Jedna z protagonistek stwierdza: „Bardziej cierpię, piję alkohol i piszę piosenki na swoją pierwszą solową płytę" (s. 88).

W Grach losowych Polska staje się mekką hipsterów. Członkowie grupy Zespót Tam Gdzie Kończy się Ironia a Zaczyna się Depresja, przyjeżdżając na warsztaty do Polski, stwierdzają:

Przyjeżdżasz do dziwnego kraju Polska, najbardziej hipsterskiego miejsca na świecie, gdzie zapoczątkowane zostały liczne trendy: choćby trend skarpety do sandałów [...] trend wąsy, trend „nie stać mnie na samochód, więc cieszę się jazdą rowerem”, trend dzielenia się z bliźnimi („,czy ma pan może końcówkę papierosa?”) (s. 128-129).

Autorka ironicznie wypowiada się na temat polskich trendów, które zainspirowały członków ponowoczesnej subkultury. Lokalna moda wynikała nie tylko z sytuacji społeczno-gospodarczej kraju, ale też pewnych naszych narodowych przywar (choćby noszenie skarpet do sandałów jako powszechny polski zwyczaj obserwowany za granica). 
Hipsterzy w powieści Dziwak to twór sztuczny, którego światopogląd podszyty jest hipokryzją. To głównie modny styl życia nowobogackiej młodzieży, eksponującej swoją ,inność” poprzez ubiór, światopogląd, muzykę. Podobnie jak dekadenci są konsumentami, znudzonymi ciągłym aktem konsumpcji ${ }^{37}$.

Zarówno hipsterzy, jak i schyłkowcy XIX wieku nieustannie poszukują źródeł inspiracji oraz stymulacji. Prymarną rolę w ich życiu odgrywa sztuka, która przez dandysów ,została uznana za najdoskonalsze zaprzeczenie natury, za twór arcyludzki, a równocześnie wspaniale czysty, nieskażony tym, co życiowe, nie mający nic wspólnego z samozachowawczym pędem zbiorowości, równie obrzydliwym jak biologiczny instynkt"38. To życie sztuką pozwala na kreowanie alternatywnej egzystencji, będącej formą buntu wobec kultury mieszczańskiej, skupionej na bezmyślnej, nieustannej konsumpcji. Warto podkreślić, iż próby kreowania oraz pielęgnowania oryginalnego image'u wymagają odpowiednich nakładów finansowych. Dlatego też mimo powszechnej krytyki stylu życia filistrów, hipsterzy oraz dekadenci nie są w stanie całkowicie z nim zerwać. Paradoksalnie buntując się przeciwko kulturze mainstreamowej sami uczestniczą w procesie konsumpcji, co zbliża ich do celebrytów, będących w centrum zainteresowania przeciętnych mieszczuchów. Dla współczesnego czytelnika zarówno dekadenci, jak i hipsterzy stają się figurami niezwykle atrakcyjnymi ze względu na odrębny styl życia, odrzucający obowiązujące konwencje obyczajowe. Alternatywna egzystencja obu subkultur okazuje się podświadomie wartością niezwykle pożądaną przez klasę średnią, metaforycznie uwięzioną w monotonnej kulturze mieszczańskiej.

\title{
Hipsters in a decadent mirror
}

\author{
Summary
}

In this article the author focuses on similarties and differences between hipsters and decadents. The members of these subcultures have many things in common. Firstly, they do not accept bourgeois culture; they criticize their lifestyle which is strictly connected with mass consumption. Secondly, they want to create their lives as a masterpiece. That is why, they mainly focus on art; they attend to many art openings where they may meet e.g. famous painters. Thirdly, they are pessimistic about their future. They believe that the war or mass destruction is inevitable. Sometimes they suffer from depression and melancholy. What is more, their original image is very crucial in their existence. Looking for original clothes is a kind of rebellion against typical dress code for townspeople. However, there is one difference between hipsters and decadents. Hipsters are more active as far as we talk about art. They are not passive as decadents; they make an attempt to create something unique in art.

37 Por. E. Paczoska, Dekadent jako towar (Gawalewicz, Mańkowski i inni), [w:] Literatura niewyczerpana. W kręgu mniej znanych twórców polskiej literatury lat 1863-1914, red. K. Fiołek, Kraków 2014, s. 58.

38 T. Walas, op. cit., s. 63. 